\title{
Inoculation of Pinus taeda Seedlings with Plant Growth-promoting Rhizobacteria
}

\author{
Rafael Fernandes dos Santos ${ }^{1}$, Sonia Purin da Cruz ${ }^{1}$, Gloria Regina Botelho ${ }^{1}$, \\ Andressa Vasconcelos Flores ${ }^{1}$ \\ ${ }^{1}$ Centro de Ciências Rurais, Universidade Federal de Santa Catarina - UFSC, Curitibanos/SC, Brasil
}

\begin{abstract}
The aim of this study was to evaluate the effect of Azospirillum brasilense, Bacillus subtilis and Pseudomonas fluorescens on the growth of Pinus taeda seedlings. Bacterial inoculants were applied in two different forms: at sowing and 20 days after emergence. At 30, 60 and 90 days after emergence, we evaluated plant height and root-colar diameter. At 180 days after emergence, we also measured shoot and root dry weight. Data were analyzed by analysis of variance and means were ranked by Duncan's test. The most pronounced results were observed for root and shoot biomass when plants were inoculated with Bacillus subtilis and Pseudomonas fluorescens. Bacillus subtilis increased root and shoot biomass by $67.1 \%$ and $33.1 \%$, respectively, when comparing values with those of non-inoculated plants. On the other hand, inoculation with Pseudomonas fluorescens decreased root biomass up to $31.42 \%$. Inoculation with Azospirillum brasilense did not promote any difference in Pinus taeda seedling growth and may not be an efficient alternative for inoculation practices. According to these results, inoculation of Pinus taeda seedlings with Bacillus subtilis has great potential to improve plant growth regarding adaptation to field conditions.
\end{abstract}

Keywords: Bacillus subtilis, Pseudomonas fluorescens, Azospirillum brasilense, biotechnology, silviculture. 


\section{INTRODUCTION}

The Brazilian forestry sector is recognized worldwide for its forestry byproducts. Pinus, along with Eucalyptus, are the most dominant tree species in commercial plantations in Brazil which in 2015 accounted for 7.8 million hectares. Of this area, $72 \%$ was cultivated with Eucalyptus and 20\% with Pinus. States such as Minas Gerais, São Paulo, Paraná, Santa Catarina and Rio Grande do Sul and Bahia have more than $98 \%$ of all land cultivated with pinus. In Santa Catarina alone, the second largest producer, pinus plantations accounted for 542,662 hectares in 2015 (ABRAF; 2013; EPAGRI, 2016).

Several European species of pinus were introduced in Brazil more than a century ago for ornamental purposes. Around 1936, the first silvicultural trials were carried out, but they were unsuccessful due to poor adaptation of these species. From 1950 on, North-American species of pinus were introduced in Brazil, mostly Pinus ellioti and Pinus taeda, due to their adaptation, faster growth and reproduction as well as easy management (Coelho \& Kwasniews, 2008). Since then, these two species have become commercially valuable and have been cultivated in large scale for reforestation and as raw material for wood and paper industries.

In order to meet the high demand for areas cultivated with pinus in Brazil, seedlings must be carefully prepared before being introduced in the field. A nursery period is necessary, in the course of which a number of silvicultural techniques are used to improve growth and field performance of pinus seedlings. Among other aspects, it is important that the substrate contains high amounts of organic matter as well as microrganisms such as ectomycorrhizal fungi, given that these are necessary for good growth and development of seedlings. One example of the benefit of these fungi is reported by Tomazello \& Krügner (1982). These authors observed that the height of Pinus echinata with ectomycorrhizae was of $7.4 \mathrm{~cm}$, while non-mycorrhizal plants were just $5.5 \mathrm{~cm}$ tall. Oliveira et al. (2012) showed that inoculation of Pinus pinaster with ectomycorrhizal fungi promoted biomass values 2.2 times higher than those observed in non-inoculated seedlings.
Along with ectomycorrhizal fungi, another group of microrganisms that are important for plant development are growth-promoting rhizobacteria, which play an essential role in plant nutrition and growth. Studies by Probanza et al. (2001) in Spain evaluated the effectiveness of two Bacillus species inoculated in Pinus pinea and described that areal and root surface, as well as root length, were two times greater in the presence of these bacteria. Other studies performed with Pseudomonas and Pinus halepensis revealed that roots from inoculated plants weighed five grams more than in non-inoculated plants. Furthermore, the presence of these bacteria increased plant height by three centimeters (Dominguez et al., 2012).

In Brazil, there are only two published studies to date on this topic (Brunetta et al., 2007, 2010). Data indicate that Pinus taeda L. seedlings inoculated with Bacillus strains were up to 3.5 centimeters taller than control plants. Additionally, shoot and root dry weights were on average 12 grams heavier after inoculation.

Although very important for inoculant production, studies about isolation of rhizobacteria from pinus species and its utilization are scarce. In fact, these bacteria increase plant growth and reduce the time needed before transfer to commercial plantations, resulting in higher quality of seedlings and enhanced survival once in the field. Therefore, the aim of this study was to evaluate the effect of different bacterial species (Azospirillum brasilense, Bacillus subtilis and Pseudomonas fluorescens) on Pinus taeda seedlings. We tested the hypothesis that the benefits of the association between rhizobacteria and Pinus taeda are variable according to the species of microorganism studied.

\section{MATERIAL AND METHODS}

This study was carried out in nursery conditions at the company "Viveiro Primon", located in the city of Curitibanos-SC, Brazil, between May 2014 and March 2015. The selected species was Pinus taeda. In order to produce seedlings, seeds were kept in a pot with water for 48 hours so that the most appropriate ones could be selected for sowing. Seeds were dried and then kept at $5^{\circ} \mathrm{C}$ for 60 days to break dormancy. Sowing was done in $55 \mathrm{~cm}^{3}$ plastic cone-tainers (eight internal vertical anti-spiral ribs, length: $120 \mathrm{~mm}$, 
top diameter: $35 \mathrm{~mm}$ ). Each cone-tainer was filled with $45 \mathrm{~mL}$ of substrate composed by NPK, pine bark and vermiculite. We conducted three experiments with different species and concentrations of bacteria, all in a completely randomized design.

\subsection{Establishment of experiments 1 and 2}

Each experiment had three treatments (two forms of inoculation and one control) and eight replications. Inoculation was performed using two methods: at sowing or 20 days after emergence.

In experiment 1 , the plant-growth promoting rhizobacteria used was Bacillus subtilis (strain CCT4391) prepared as a liquid inoculant by the company "Total Biotecnologia", located in Curitiba-PR, Brazil. Bacterial concentration in the inoculant was of $2 \times 10^{7} \mathrm{UFC} / \mathrm{mL}$. We applied an amount of $6.75 \mathrm{ml}$ per cone-tainer, therefore the final concentration of bacteria in the substrate was $3 \times 10^{6} \mathrm{UFC} / \mathrm{g}$. In experiment 2 , the tested plant-growth promoting rhizobacteria was Pseudomonas fluorescens (strain CCTB 03=CNPSo 2719), used as liquid inoculant prepared by the same company. The concentration of bacterial cells was of $2 \times 10^{8} \mathrm{UFC} / \mathrm{mL}$ of inoculant. A volume of $2.7 \mathrm{ml}$ was applied to each cone-tainer, producing a final concentration of $12 \times 10^{6}$ UFC per gram of substrate.

At sowing, inoculants were first mixed with the substrate in plastic trays and then this mixture was placed in the cone-tainers. Two-three seeds were placed in each cone-tainer and vermiculite was added to cover seeds.

At post-emergence, inoculants were pippeted in the substrate, near to seedling colar. Application was done after seed emergence and thinning. Inoculants were applied with sterile pipets at the depth of $2-3 \mathrm{~cm}$. Non-inoculated plants did not receive any type of inoculant or other material.

After being inoculated, seedlings were kept for 180 days at the company "Viveiro Primon", under routine nursery care and tending.

\subsection{Establishment of experiment 3}

This experiment was conducted in a completely randomized design with two treatments (inoculated and non-inoculated seedlings) and eight replications. Inoculant was applied at both sowing and post-emergence.
Azospirillum brasilense (strains Ab-V5 and Ab-V6; $2 \times 10^{8} \mathrm{UFC} / \mathrm{mL}$ ) was the plant-growth promoting rhizobacteria used as liquid inoculant produced by Total Biotecnologia. We applied an amount of $2.7 \mathrm{ml}$ per cone-tainer at each inoculation procedure; therefore the final concentration of bacteria in the substrate was $24 \times 10^{6} \mathrm{UFC} / \mathrm{g}$. Seedling inoculation and maintenance procedures adopted in this experiment were the same as applied in experiments 1 and 2 .

\subsection{Data collection and analysis of the three experiments}

At 30, 60 and 90 days after emergence, we evaluated plant height and root-colar diameter. Plant height was measured with a ruler, placed at the top of the cone-tainer and aligned with the last needle. Root-colar diameter was measured at the top of the cone-tainer with a digital pachymeter.

At 180 days after emergence, we evaluated plant height, root-colar diameter and shoot and root dry weights. Shoots and roots were initially separated and then placed in paper bags that were kept at $65^{\circ} \mathrm{C}$. When completely dried, shoots and roots were weighed. Dickson Quality Index of seedlings in each treatment was determined as described in Dickson et al. (1960).

First, data normality and homogeneity were verified by Shapiro-Wilk's test. Data were then submitted to analysis of variance (ANOVA) and means were separated at $5 \%$ by Duncan's Test. All procedures were done using the software Assistat (Silva \& Azevedo, 2002).

\section{RESULTS}

When evaluating the effects of inoculation with Bacillus subtilis, it was demonstrated that seedling height and diameter were not affected on any sampling occasion by any of the tested treatments (Table 1). At 180 DAE, positive inoculation effects on root and shoot dry weight were reported (Table 1).

Likewise, inoculation with Pseudomonas fluorescens did not affect means of height or diameter in Pinus taeda seedlings (Table 2). At 180 DAE, shoot dry weight was reduced in both inoculation treatments. The mean value of root dry weight was lower in treatment 2 compared to treatments 1 and 3 (Table 2). 
Inoculation with Azospirillum brasilense increased root-colar diameter at $30 \mathrm{DAE}$. On the other hand, plant height was not affected by inoculation at the same sampling date (Table 3). At $90 \mathrm{DAE}$, a negative effect of inoculation on height was observed, but diameter was not affected. Means of shoot and root dry weight were not statistically different between treatments (Table 3 ).

Values of Dickson Quality Index varied between 0.20 and 0.30 between different experiments and treatments (Table 4 ).

\section{DISCUSSION}

Bacillus subtilis promoted a higher positive effect on root and shoot dry weight of Pinus taeda seedlings, increasing root dry weight by $67.1 \%$ and shoot dry weight by $33.1 \%$, respectively (Table 1 ). It is important to highlight that bacteria in this inoculant were applied in smaller concentrations in comparison with the concentration of the two other inoculants used in this experiment. Of all the tested bacteria, B. subtilis was the species with the best effects on $P$. taeda seedlings. It is possible that application of this bacterium in small concentrations may have contributed to the reported stimulus on plant growth. Indeed, previous studies show that the effect of rhizobacteria may be variable depending on the dose being tested (Vargas \& Suhet, 1980; Brandão \& Hungria, 2000).

Probanza et al. (2002) inoculated Pinus pinea with Bacillus sp. and detected an average increase of $100 \%$ on shoot dry weight compared to the absence of bacteria. Another study developed by Brunetta et al. (2010) tested

Table 1. Means of height, root-colar diameter, shoot and root dry weight of Pinus taeda seedlings at 30, 60, 90 and 180 days after emergence (DAE), inoculated with Bacillus subtilis. T1: Control; T2: Inoculation at sowing; T3: Post-emergence inoculation.

\begin{tabular}{|c|c|c|c|c|c|c|c|c|c|c|}
\hline & \multicolumn{2}{|c|}{$30 \mathrm{DAE}$} & \multicolumn{2}{|c|}{60 DAE } & \multicolumn{2}{|c|}{90 DAE } & \multicolumn{4}{|c|}{$180 \mathrm{DAE}$} \\
\hline & $\begin{array}{l}\text { Height } \\
\text { (cm) }\end{array}$ & $\begin{array}{l}\text { Diameter } \\
(\mathrm{cm})\end{array}$ & $\begin{array}{c}\text { Height } \\
(\mathrm{cm})\end{array}$ & $\begin{array}{l}\text { Diameter } \\
(\mathbf{c m})\end{array}$ & $\begin{array}{l}\text { Height } \\
(\mathrm{cm})\end{array}$ & $\begin{array}{l}\text { Diameter } \\
(\mathrm{cm})\end{array}$ & $\begin{array}{l}\text { Height } \\
\text { (cm) }\end{array}$ & $\begin{array}{l}\text { Diameter } \\
(\mathrm{cm})\end{array}$ & $\begin{array}{c}\text { Shoot } \\
\text { (g) }\end{array}$ & $\begin{array}{c}\text { Root } \\
\text { (g) }\end{array}$ \\
\hline $\mathrm{T} 1$ & $6.46 \mathrm{~ns}^{*}$ & $1.08 \mathrm{~ns}$ & $14.06 \mathrm{~ns}$ & $1.58 \mathrm{~ns}$ & $16.45 \mathrm{~ns}$ & $2.01 \mathrm{~ns}$ & $26.50 \mathrm{~ns}$ & $3.52 \mathrm{~ns}$ & $1.51 b^{\star *}$ & $0.70 \mathrm{~b}$ \\
\hline $\mathrm{T} 2$ & 6.98 & 1.14 & 14.35 & 1.69 & 19.15 & 2.28 & 27.78 & 3.72 & $2.01 \mathrm{a}$ & $1.17 \mathrm{a}$ \\
\hline $\mathrm{T} 3$ & 6.00 & 1.05 & 14.39 & 1.73 & 19.20 & 2.26 & 27.68 & 3.66 & $1.76 \mathrm{ab}$ & $1.06 \mathrm{a}$ \\
\hline
\end{tabular}

${ }^{*}$ Not statistically different $(\mathrm{p}<0.05)$ according to the ANOVA; ${ }^{* *}$ Means followed by the same letter are not statistically different $(\mathrm{p}<0.05)$ according to Duncan's test.

Table 2. Means of height, root-colar diameter, shoot and root dry weight of Pinus taeda seedlings at 30, 60, 90 and 180 days after emergence (DAE), inoculated with Pseudomonas fluorescens. T1: Control; T2: Inoculation at sowing; T3: Post-emergence inoculation.

\begin{tabular}{|c|c|c|c|c|c|c|c|c|c|c|}
\hline & \multicolumn{2}{|c|}{30 DAE } & \multicolumn{2}{|c|}{$60 \mathrm{DAE}$} & \multicolumn{2}{|c|}{90 DAE } & \multicolumn{4}{|c|}{$180 \mathrm{DAE}$} \\
\hline & $\begin{array}{c}\text { Height } \\
(\mathrm{cm})\end{array}$ & $\begin{array}{c}\text { Diameter } \\
(\mathrm{cm})\end{array}$ & $\begin{array}{c}\text { Height } \\
\text { (cm) }\end{array}$ & $\begin{array}{c}\text { Diameter } \\
(\mathrm{cm})\end{array}$ & $\begin{array}{c}\text { Height } \\
\text { (cm) }\end{array}$ & $\begin{array}{c}\text { Diameter } \\
(\mathrm{cm})\end{array}$ & $\begin{array}{c}\text { Height } \\
(\mathrm{cm})\end{array}$ & $\begin{array}{l}\text { Diameter } \\
(\mathbf{c m})\end{array}$ & $\begin{array}{c}\text { Shoot } \\
\text { (g) }\end{array}$ & $\begin{array}{c}\text { Root } \\
\text { (g) }\end{array}$ \\
\hline $\mathrm{T} 1$ & $6.76 \mathrm{~ns}^{\star}$ & $1.09 \mathrm{~ns}$ & $14.52 \mathrm{~ns}$ & $1.63 \mathrm{~ns}$ & $19.35 \mathrm{~ns}$ & $2.26 \mathrm{~ns}$ & $25.52 \mathrm{~ns}$ & $3.52 \mathrm{~ns}$ & $1.95 \mathrm{a}^{\star *}$ & $0.92 \mathrm{a}$ \\
\hline $\mathrm{T} 2$ & 7.07 & 1.02 & 14.45 & 1.69 & 18.90 & 2.33 & 26.02 & 3.44 & $1.56 \mathrm{~b}$ & $0.70 \mathrm{~b}$ \\
\hline T3 & 6.48 & 1.00 & 14.53 & 1.57 & 18.67 & 2.27 & 26.43 & 3.54 & $1.47 \mathrm{~b}$ & $0.85 \mathrm{a}$ \\
\hline
\end{tabular}

${ }^{*}$ Not statistically different $(\mathrm{p}<0.05)$ according to the ANOVA; ${ }^{* *}$ Means followed by the same letter are not statistically different $(\mathrm{p}<0.05)$ according to Duncan's test.

Table 3. Means of height, root-collar diameter, shoot and root dry mass of Pinus taeda seedlings at 30, 60,90 and 180 days after emergence (DAE), inoculated with Azospirillum brasilense. T1: Control; T2: Inoculation in the substrate.

\begin{tabular}{|c|c|c|c|c|c|c|c|c|c|c|}
\hline & \multicolumn{2}{|c|}{30 DAE } & \multicolumn{2}{|c|}{$60 \mathrm{DAE}$} & \multicolumn{2}{|c|}{90 DAE } & \multicolumn{4}{|c|}{$180 \mathrm{DAE}$} \\
\hline & $\begin{array}{c}\text { Height } \\
\text { (cm) }\end{array}$ & $\begin{array}{c}\text { Diameter } \\
(\mathrm{cm})\end{array}$ & $\begin{array}{c}\text { Height } \\
\text { (cm) }\end{array}$ & $\begin{array}{c}\text { Diameter } \\
(\mathrm{cm})\end{array}$ & $\begin{array}{c}\text { Height } \\
\text { (cm) }\end{array}$ & $\begin{array}{c}\text { Diameter } \\
(\mathbf{c m})\end{array}$ & $\begin{array}{c}\text { Height } \\
\text { (cm) }\end{array}$ & $\begin{array}{c}\text { Diameter } \\
(\mathrm{cm})\end{array}$ & $\begin{array}{l}\text { Shoot } \\
\text { (g) }\end{array}$ & $\begin{array}{l}\text { Root } \\
\text { (g) }\end{array}$ \\
\hline $\mathrm{T} 1$ & $7.22 \mathrm{~ns}^{*}$ & $1.01 b^{* *}$ & $14.58 \mathrm{~ns}$ & $1.65 \mathrm{~ns}$ & $20.50 \mathrm{a}$ & $2.26 \mathrm{~ns}$ & $26.61 \mathrm{~ns}$ & $3.55 \mathrm{~ns}$ & $1.48 \mathrm{~ns}$ & $0.88 \mathrm{~ns}$ \\
\hline $\mathrm{T} 2$ & 6.90 & $1.10 \mathrm{a}$ & 14.02 & 1.77 & $18.65 b$ & 2.32 & 27.36 & $3.49 \mathrm{~ns}$ & 1.62 & 0.99 \\
\hline
\end{tabular}

${ }^{*}$ Not statistically different $(\mathrm{p}<0.05)$ according to the ANOVA; ${ }^{* *}$ Means followed by the same letter are not statistically different $(\mathrm{p}<0.05)$ according to Duncan's test. 
Table 4. Dickson Quality Index in Pinus taeda seedlings 180 days after emergence, inoculated with different species of bacteria.

\begin{tabular}{cccc}
$\begin{array}{c}\text { Treat- } \\
\text { ment }\end{array}$ & $\begin{array}{c}\text { Bacillus } \\
\text { subtilis }\end{array}$ & $\begin{array}{c}\text { Pseudomonas } \\
\text { fluorescens }\end{array}$ & $\begin{array}{c}\text { Azospirillum } \\
\text { brasilense }\end{array}$ \\
T1 & 0.22 & 0.30 & 0.25 \\
T2 & 0.34 & 0.23 & 0.27 \\
T3 & 0.30 & 0.25 & - \\
\hline
\end{tabular}

T1: control; T2: inoculation in the substrate; T3: post-emergence inoculation

the effects of inoculating the same genus of bacteria on Pinus taeda. These authors did not observe differences in shoot dry weight when inoculation was performed in the coldest season of the year. However, they did report that inoculated plants were two centimeters taller than the non-inoculated ones.

No height difference was observed between 30 and 90 DAE and this may be explained by the fact that the experiment was carried out during winter, when temperatures may reach negative values in Santa Catarina. According to Carneiro (1995), it is recommended to grow pinus seedlings during spring, which may help to explain the absence of effects in our experiment. Previous studies indicate that climate and temperature strongly affect growth of pinus species, and attention should be paid in states such as Santa Catarina, where cold air and strong winds are prevalent during the winter (Wrege et al., 2014). Low temperatures in the city of Curitibanos-SC, mainly when the experiment was established, may have limited the effects of inoculation in the present study. In fact, similar studies show that effects of inoculation with Bacillus sp. are absent during colder periods of the year (Brunetta et al., 2010).

Additionally, no effect of inoculation on root-colar diameter was observed, in contrast to what Barriuso et al. (2008) reported. They found that the diameter of inoculated plants was $4.0 \mathrm{~mm}$ larger than non-inoculated plants. On the other hand, our data confirmed findings from Brunetta et al. (2010), who observed no difference in root-colar diameter when plants were inoculated with Bacillus sp.

In our study, means of root dry weight were $67.1 \%$ higher with inoculation. The positive effect of Bacillus sp. is confirmed by Barriuso et al. (2008), who reported a $20 \%$ increase of root dry weight. Also, Brunetta et al. (2010) obtained 33\% more root dry weight when inoculating pinus with a Bacillus subtilis isolate. Conversely, Probanza et al. (2002) evaluated the effects of Bacillus sp. on root dry weight but found no differences between treatments.

An average increase of $0.5 \mathrm{~g}$ on shoot dry weight per plant was achieved with inoculation (Table 1). Comparing these findings to those from Brunetta et al. (2010), it may be suggested that inoculation with Bacillus subtilis has a positive effect on aerial plant growth. The referred authors noticed that shoots of inoculated plants weighed 0.15 grams more than non-inoculated plants.

The benefits of inoculation with Bacillus subtilis have also been observed in other forestry species. Raasch et al. (2013) demonstrated that inoculation increased root biomass of eucalyptus seedlings by up to $50 \%$. Hence, this bacterium may be recommended to improve seedling quality and accelerate pinus development under nursery conditions.

Inoculation with Pseudomonas fluorescens did not affect plant height or diameter at any sampling time. Regarding shoot development, all inoculated seedlings had smaller values of dry weight than non-inoculated seedlings (Table 2). Concerning root growth, seedlings that received inoculants at sowing had lower dry weight values compared to seedlings that received the bacterial inoculant after emergence (Table 2). Comparisons between the present study and other research reports are not possible given that no experiments with Pseudomonas fluorescens or Pinus taeda have been performed, as far as we are aware. Previous research has been carried with the same bacterium, but different plant species.

Dominguez-Nuñez et al. (2015) noticed that Pinus halepensis seedlings inoculated with Pseudomonas fluorescens had a $26 \%$ wider root-colar diameter. Shoot dry weight was also greater in inoculated plants, but height and root dry weight were not influenced by inoculation. Dominguez et al. (2012) showed that the benefits of inoculating Pinus halepensis with Pseudomonas fluorescens on root dry weight and height were more pronounced, which were 50 and $31 \%$ greater, respectively. Neither diameter nor shoot dry weight were affected by inoculation.

Overall, it is likely that results of inoculation of pinus species with $P$. fluorescens are conflicting. It is possible that factors such as climate and environment 
may interfere in inoculation effects. Additionally, each plant species have unique adaptation and response patterns to substrate and nursery conditions. Even genetic factors (from both bacteria and plant species) may play a role in the outcome of inoculation practices, and determining the significance of all these factors will require more detailed study.

According to this experiment, we may suggest that Pinus taeda does not respond well to inoculation with P. fluorescens in the central region of Santa Catarina. In fact, inoculation with this bacterium can even reduce seedling growth. Based on the current findings, the use of $P$. fluorescens is not a promising alternative to stimulate $P$. taeda seedling growth under nursery conditions.

Inoculation with Azospirillum brasilense did not affect Pinus taeda at any time other than at 90 DAE, when inoculation decreased plant height by $1.85 \mathrm{~cm}$ (Table 3). The lack of similar studies with inoculum of Azospirillum brasilense and P. taeda seedlings limits direct comparisons with the present study. Based on our research, it is possible to state that inoculation with this bacterial species may not be favorable to the development of $P$. taeda in nurseries, although several studies prove the benefits of $A$. brasilense for agricultural crops.

Hungria (2011) affirms that the association of grasses with $A$. brasilense increased wheat yield between 13 and $18 \%$, while corn yield was improved by $24-30 \%$. A study by Pedrinho et al. (2010) shows that inoculated corn plants had significant gains in shoot and root dry weight, as well as height, compared to non-inoculated plants. The increase observed in these parameters was of $4.02,1.13$ and $12.42 \mathrm{~g}$, respectively. More detailed studies regarding the effects of this bacterium on forestry species are needed once its benefits for crops have been well defined.

The higher values of Dickson's Quality Index values (DQI) were observed when using the bacteria Bacillus subtilis and Azospirilum brasilense (Table 4). Taking the minimum value of 0.20 established by Dickson et al. (1960) as a standard, we may state that $P$. taeda seedlings are within a satisfactory range known to indicate seedling quality (Thomas, 2007). Also, Binotto (2007) evaluated the DQI values in Pinus elliotti seedlings at several stages after emergence and reported values of 0.22 and 0.25 at 150 and 175 DAE.
When comparing values from the current study to those found by Brunetta et al. (2010), it is remarkable that inoculation with Bacillus sp. increases the quality of $P$. taeda seedlings. The previously mentioned authors reported that DQI was 0.15 in non-inoculated plants and 0.26 in inoculated plants. Overall, these DQI values may be considered suitable and inoculation may be a promising alternative to increase this parameter in P. taeda seedlings.

\section{CONCLUSIONS}

Bacillus subtilis may be recommended to inoculate P. taeda and this bacterium should be integrated in silvicultural practices to promote and stimulate seedling growth. On the other hand, Pseudomonas fluorescens may cause negative effects on $P$. taeda seedlings and the use of this inoculant is not recommended. Azospirillum brasilense does not seem to affect $P$. taeda development, although its efficiency in crop species has been consistently recognized.

\section{SUBMISSION STATUS}

Received: 25 nov., 2016

Accepted: 5 aug., 2017

\section{CORRESPONDENCE TO}

\section{Rafael Fernandes dos Santos}

Centro de Ciências Rurais, Universidade Federal de Santa Catarina - UFSC, Rodovia Ulysses Gaboardi, CEP 89520-000, Curitibanos, SC, Brasil

e-mail: rafaelfernandes.santtos@gmail.com

\section{REFERENCES}

Associação Brasileira de Produtores de Florestas Plantadas - ABRAF. Anuário estatístico ABRAF 2013 Ano base 2012. Brasília: ABRAF; 2013.

Barriuso J, Solano BR, Santamaria C, Daza A, Gutiérrez Mañero FJ. Effect of inoculation with putative plant growth-promoting rhizobacteria isolated from Pinus spp. on Pinus pinea growth, mycorrhization and rhizosphere microbial communities. Journal of Applied Microbiology 2008; 105(5): 1298-1309. http://dx.doi.org/10.1111/j.13652672.2008.03862.x. PMid:18713291. 
Binotto AF. Relação entre variáveis de crescimento e o indice de qualidade de Dickson em mudas de Eucalyptus grandis W. Hill ex Maid e Pinus elliottii var. elliottii Engelm [dissertação]. Santa Maria: Universidade Federal de Santa Maria; 2007.

Brandão O Jr, Hungria M. Efeito de doses de inoculante turfoso na fixação biológica do nitrogênio pela cultura da soja. Revista Brasileira de Ciência do Solo 2000; 24(3): 527 535. http://dx.doi.org/10.1590/S0100-06832000000300006.

Brunetta JMFC, Alfenas AC, Mafia RG, Gomes JM, Binoti DB, Fonseca EP. Avaliação da especificidade de rizobactérias isoladas de diferentes espécies de Pinus sp. Revista Árvore 2007; 31(6): 1027-1033. http://dx.doi. org/10.1590/S0100-67622007000600007.

Brunetta JMFC, Alfenas AC, Mafia RG, Gomes JM, Binoti DB, Fonseca EP. Isolamento e seleção de rizobactérias promotoras do crescimento de Pinus taeda. Revista Árvore 2010; 34(3): 399-406. http://dx.doi.org/10.1590/ S0100-67622010000300003.

Carneiro JGA. Produção e controle de qualidade de mudas florestais. Curitiba: Universidade Federal do Paraná; 1995.

Coelho MH, Kwasniews CM. Aspectos econômicos do reflorestamento de Pinus na pequena propriedade rural: um estudo de caso [online]. In: $4^{\circ}$ Encontro de Engenharia e Tecnologia dos Campos Gerais; 2008; Ponta Grossa. Ponta Grossa: Associação dos Engenheiros e Arquitetos de Ponta Grossa. p. 1-12. [cited 2014 Apr 15]. Available from: http:www.4eetcg.uepg.br/oral/47_1.pdf

Dickson A, Leaf AL, Hosner JF. Quality appraisal of white spruce and white pine seedling stock in nurseries. Forestry Chronicle 1960; 36(1): 10-13. http://dx.doi.org/10.5558/ tfc36010-1.

Dominguez JA, Martin A, Anriquez A, Albanesi A. The combined effects of Pseudomonas fluorescens and Tuber melanosporum on the quality of Pinus halepensis seedlings. Mycorrhiza 2012; 22(6): 429-436. http://dx.doi.org/10.1007/ s00572-011-0420-0. PMid:22068563.

Dominguez-Nuñez JAD, Alvez DD, Lobo MB, Anriquez A, Albanesi A. Controlled-release fertilizers combined with Pseudomonas fluorescens rhizobacteria inoculum improve growth in Pinus halepensis seedlings. iForest Biogeosciences and Forestry 2015; 8: 12-18. http://dx.doi. org/10.3832/ifor1110-007.

Empresa de Pesquisa Agropecuária e Extensão Rural de Santa Catarina - EPAGRI; Centro de Socioeconomia e Planejamento Agrícola - CEPA. Síntese Anual da Agricultura de Santa Catarina - 2015-2016 [online]. Florianópolis: Epagri; Cepa; 2016. [cited 2017 Feb 1]. Available from: http://docweb.epagri.sc.gov.br/website_cepa/publicacoes/ Sintese_2016.pdf

Hungria M. Inoculação com Azospirillum brasilense: inovação em rendimento a baixo custo. Londrina: Embrapa Soja, 2011.

Oliveira RS, Franco AR, Castro PML. Combined use of Pinus pinaster plus and inoculation with selected ectomycorrhizal fungi as an ecotechnology to improve plant performance. Ecological Engineering 2012; 43: 95103. http://dx.doi.org/10.1016/j.ecoleng.2012.01.021.

Pedrinho EAN, Galdiano RF Jr, Campanharo JC, Alves LMC, Lemos EGM. Identificação e avaliação de rizobactérias isoladas de raízes de milho. Bragantia 2010; 69(4): 905-911. http://dx.doi.org/10.1590/S0006-87052010000400017.

Probanza A, Lucas García JA, Ruiz Palomino M, Ramos B, Gutiérrez Mañero FJ. Pinus pinea L. seedling gowth and bacterial rhizosphere structure after inoculation with PGPR Bacillus (B. licheniformis CECT 5106 and B. pumilus CECT 5105). Applied Soil Ecology 2002; 20(2): 75-84. http://dx.doi.org/10.1016/S0929-1393(02)00007-0.

Probanza A, Mateos JL, Lucas Garcia JA, Ramos B, Felipe MR, Gutierrez Manero FJ. Effects of inoculation with PGPR Bacillus and Pisolithus tinctorius on Pinus pinea L. growth, bacterial rhizosphere colonization, and mycorrhizal infection. Microbial Ecology 2001; 41(2): 140-148. http:// dx.doi.org/10.1007/s002480000081. PMid:12032619.

Raasch LD, Bonaldo SM, Oliveira AAF. Bacillus subtilis: enraizamento e crescimento de miniestacas de eucalipto em Sinop, norte de Mato Grosso. Bioscience Journal 2013; 29(1): 1446-1457.

Silva FAS, Azevedo CAV. Versão do programa computacional Assistat para o sistema operacional Windows. Revista Brasileira de Produtos Agroindustriais 2002; 4(1): 71-78. http://dx.doi.org/10.15871/1517-8595/rbpa.v4n1p71-78.

Thomas R. Crescimento e nutrição de mudas de Pinus taeda L. no estado do Rio Grande do Sul. Santa Maria: Universidade Federal de Santa Maria; 2007.

Tomazello M Fo, Krügner TL. Aspectos da associação micorrízica em Pinus spp. Vol. 3. Piracicaba: IPEF; 1982. p. 1-32. (Série Técnica, no. 9).

Vargas MAT, Suhet AR. Efeito de tipos e níveis de inoculantes na soja cultivada em um solo de Cerrados. Pesquisa Agropecuária Brasileira 1980; 15: 343-347.

Wrege MS, Fritzons E, Shimizu JY, Aguiar AV, Caramori $\mathrm{PH}$. Pinus tropical com potencial para uso em plantios comerciais no Brasil. Revista do Instituto Florestal 2014; 26(2): 137-145. http://dx.doi.org/10.4322/rif.2014.010. 